\title{
A new application of a sodium deoxycholate-propidium monoazide- quantitative PCR assay for rapid and sensitive detection of viable Cronobacter sakazakii in powdered infant formula
}

\author{
Baoqing Zhou, ${ }^{*}$ Bolu Chen, ${ }^{*}$ Xin Wu,† Fan Li, ${ }^{*}$ Pei Yu, ${ }^{*}$ Zoraida P. Aguilar, $\ddagger$ Hua Wei, ${ }^{*}$ and Hengyi $\mathrm{Xu}^{* 1}$ \\ *State Key Laboratory of Food Science and Technology, Nanchang University, Nanchang, 330047, PR China \\ †Jiang Xi Institute for Food Control, Nanchang, 330047, PR China \\ †Zystein LLC, Fayetteville, AR 72704
}

\begin{abstract}
A rapid, reliable, and sensitive method for the detection of Cronobacter sakazakii, a common foodborne pathogen that may cause serious neonatal disease, has been developed. In this study, a rapid real-time quantitative PCR (qPCR) assay combined with sodium deoxycholate (SD) and propidium monoazide (PMA) was developed to detect $C$. sakazakii contamination in powdered infant formula (PIF). This method could eliminate the interference from dead or injured bacteria. Optimization studies indicated that $\mathrm{SD}$ and $\mathrm{PMA}$ at $0.08 \%(\mathrm{wt} / \mathrm{vol}$ ) and $5 \mu \mathrm{g} / \mathrm{mL}$, respectively, were the most appropriate. In addition, qPCR, PMA-qPCR, SD-PMA-qPCR, and plate count assays were used to account for the number of viable bacteria in cell suspensions that were exposed to a $55^{\circ} \mathrm{C}$ water bath at different length of time. As a result, the viable number by PMA-qPCR showed significantly higher than of the number from SD-PMA-qPCR or plate counts. The number of viable bacteria was consistent between SD-PMA-qPCR and traditional plate counts, which indicated that SD treatment could eliminate the interference from dead or injured cells. Using the optimized parameters, the limit of detection with the SD-PMAqPCR assay was $3.3 \times 10^{2} \mathrm{cfu} / \mathrm{mL}$ and $4.4 \times 10^{2} \mathrm{cfu} / \mathrm{g}$ in pure culture and in spiked PIF, respectively. A similar detection limit of $5.6 \times 10^{2} \mathrm{cfu} / \mathrm{g}$ was obtained in the presence of the Staphylococcus aureus $\left(10^{7} \mathrm{cfu} / \mathrm{mL}\right)$. The combined SD-PMA-qPCR assay holds promise for the rapid detection of viable $C$. sakazakii in PIF.
\end{abstract}

Key words: Cronobacter sakazakii, sodium deoxycholate, propidium monoazide, quantitative PCR

Received May 31, 2016.

Accepted August 26, 2016.

${ }^{1}$ Corresponding author: kidyxu@163.com or HengyiXu@ncu.edu.cn

\section{INTRODUCTION}

Cronobacter sakazakii is a member of the Enterobacteriaceae family; its name was changed from "yellowpigmented Enterobacter cloacae" in 1980 (Farmer et al., 1980). It belongs to a group of gram-negative rods, oxidase-negative, catalase-positive, facultative anaerobic, peritrichous, and generally motile bacteria (Iversen et al., 2008). Cronobacter sakazakii is a commonly reported foodborne pathogen that can cause life-threatening meningitis, sepsis, and necrotizing enterocolitis in neonates (van Acker et al., 2001; World Health Organization, 2004; Norberg et al., 2012; Hunter and Bean, 2013). Many studies reported that powdered infant formula (PIF) is the main route of infection for these diseases and with 40 to $80 \%$ fatality rate to newborns (Liu et al., 2006a; Norberg et al., 2012; Cai et al., 2013). Cronobacter sakazakii infections in neonates have aroused wide attention all over the world. The Food and Agriculture Organization of the United Nations (FAO) and the World Health Organization have focused on the issue that the PIF contaminated with C. sakazakii and Salmonella has caused serious illness in infants (World Health Organization, 2004; FAO, 2008). Thus, a sensitive, rapid, and accurate detection method is urgently needed to identify C. sakazakii for the prevention of its transmission in PIF.

To date, various diagnostic and testing techniques have been developed for the detection of C. sakazakii including the widely used traditional microbiological methods that requires laborious operation and long processing time (Park et al., 2012). Alternatively, the ordinary PCR assay has been used for detection of $C$. sakazakii because of its simplicity and rapidity. Chen et al. (2013) designed primers for the sequence of the gyrB gene for PCR assay to rapidly detect C. sakazakii. Compared with conventional PCR, real-time quantitative PCR (qPCR) has been widely used to detect and identify C. sakazakii in various food products because of its high sensitivity and accuracy. In some studies, the target sequences in the outer membrane protein 
A (ompA) gene (Zimmermann et al., 2014), the 16S23S rRNA internal transcribed spacer (ITS; Liu et al., 2006a), the $16 S$ rRNA gene (Kang et al., 2007), and the $c g c A$ gene (Hu et al., 2016) were used to specifically detect C. sakazakii. However, general qPCR could not identify viable from dead or injured cells. During the amplification phase, DNA from dead or injured cells could serve as qPCR template to generate positive signals, which could cause false-positive results. To overcome these limitations, researchers used propidium monoazide (PMA) combined with qPCR (PMA-qPCR) to remove the interference from dead cells during the amplification process of PCR (Yang et al., 2011; Xiao et al., 2015; Truchado et al., 2016). Propidium monoazide as a DNA-intercalating dye could selectively permeate through the half-baked cell membrane of dead or injured cells. Propidium monoazide could be covalently cross-linked with DNA when exposed to light to form a stable DNA modification that inhibits PCR amplification (Xiao et al., 2015). Dead or injured cells with a remaining outer membrane could serve as a protective barrier to prevent PMA permeation. As a result, some DNA from dead cells or injured cells cannot be inhibited during the PCR amplification phase (Fittipaldi et al., 2012; Nkuipou-Kenfack et al., 2013). Sodium deoxycholate (SD) as a detergent could disrupt cell membranes and change their permeability; thereafter, other molecules could penetrate into bacterial cells. Treatment with SD before PMA has been more effective in permeating dead cells or injured cells, which reduces the false-positive results (Yang et al., 2011; Nkuipou-Kenfack et al., 2013; Wang et al., 2014a,b).

In this study, we developed a SD-PMA-qPCR assay for rapid and accurate detection of viable C. sakazakii in PIF. The specific primers were designed based on the sequence of the ITS of C. sakazakii (Liu et al., 2006a,b). A SD treatment before PMA that could selectively detect viable $C$. sakazakii in pure culture was adopted into the assay. In this study, we compared the accuracy of the SD-PMA-qPCR with qPCR, PMA-qPCR, and plate count assays. To exhibit real-world application, the newly developed SD-PMA-qPCR assay for C. sakazakii was also applied for the detection of detect viable bacteria in PIF.

\section{MATERIALS AND METHODS}

\section{Preparation of Bacterial Strains}

The strains used in this study are listed in Table 1. Cronobacter strains, as well as the other bacteria strains, were cultured in Luria-Bertani (LB) medium in a rotary shaker at $180 \mathrm{rpm}$ and $37^{\circ} \mathrm{C}$. All cell pellets were suspended in sterile PBS (0.01 $M, \mathrm{pH} 7.4)$ to obtain 10 serial dilutions. The plate count method was used for enumerating viable cells that were grown on $\mathrm{LB}$ agar plates at $37^{\circ} \mathrm{C}$ for $12 \mathrm{~h}$. To obtain dead cells, the cell suspensions were heated to $80^{\circ} \mathrm{C}$ for 5 min and the viability of the bacteria was confirmed by plating on LB agar plates for $24 \mathrm{~h}$. For the optimal SD concentration studies, bacteria at $10^{7} \mathrm{cfu} / \mathrm{mL}$ were heated in a water bath at $70^{\circ} \mathrm{C}, 65^{\circ} \mathrm{C}, 60^{\circ} \mathrm{C}, 55^{\circ} \mathrm{C}$, and $50^{\circ} \mathrm{C}$, respectively. The numbers of surviving cells were enumerated on $0.3 \%$ sodium pyruvate LB plates $(0.3 \%$ LB) in an overnight culture.

\section{Exploring Optimal SD Concentration}

Earlier reports found that injured pathogenic bacterial cells lost their ability to infect hosts under normal conditions (Linder and Oliver, 1989; Morgan et al., 1993); a much more complicated and rare condition (with high and specific nutrients) is needed for recovery of injured cells to an active state, and thus injured cells could not become a hazard especially in regular conditions (e.g., food matrices). Therefore, in regular PIF matrices, injured cells could not recover to become a hazard for neonates. It is necessary to inhibit the injured cells by SD treatment. To optimize the concentration of SD for permeating the injured cells, a cell suspension $\left(10^{7} \mathrm{cfu} / \mathrm{mL}\right)$ was heat-treated in a water bath at $55^{\circ} \mathrm{C}$ for $2.5 \mathrm{~min}$ and immediately cooled at $4^{\circ} \mathrm{C}$ in an ice bath for $5 \mathrm{~min}$ (Arroyo et al., 2009), followed by centrifugation at $8,000 \times g$ for 5 min at room temperature, and the pellet was resuspended in $500 \mu \mathrm{L}$ of PBS, which was expected to cause a reduction in the number of viable C. sakazakii between 1 and $2 \log$ units (Yang et al., 2011). Five grams of SD was prepared in a $0.1 \%(\mathrm{wt} / \mathrm{vol})$ peptone water to obtain $10 \%$ (wt/vol) SD stock solution. Serial dilutions of SD from the $10 \%$ (wt/vol) stock solution were prepared by mixing with $500 \mu \mathrm{L}$ of injured cell suspension to obtain final SD concentrations: $0,0.02,0.04,0.08,0.1$, and $0.5 \%$. These were then incubated at $37^{\circ} \mathrm{C}$ for $30 \mathrm{~min}$ in a $180 \mathrm{rpm}$ rotary shaker. To recover the injured cells and enumerate the number of surviving cells, LB plates and $0.3 \%$ LB plates were prepared. Ultimately, the numbers of viable cells were determined by plate count method on an LB plate. The numbers of viable and injured cells that remained reproductive were determined by plate count method on the $0.3 \%$ LB plate. All samples were carried out in triplicate. The working principle behind the use of SD is shown in Figure 1A.

\section{Optimization of PMA Concentration}

To optimize the PMA concentration, viable and dead cells were prepared similarly as the previous sec- 
Table 1. Bacteria strains used in this study and the results of the PCR assay

\begin{tabular}{|c|c|c|c|c|}
\hline \multirow{2}{*}{$\begin{array}{l}\text { Bacteria species } \\
\text { Cronobacter sakazakii }(\mathrm{n}=14)\end{array}$} & \multicolumn{2}{|c|}{ Strain identification no. } & \multirow{2}{*}{$\frac{\text { Source }}{\text { CMCC }}$} & \multirow{2}{*}{$\begin{array}{c}\text { PCR positive } \\
\text { for } I T S^{2} \\
+\end{array}$} \\
\hline & 45401 & 45402 & & \\
\hline & 21564 & 21544 & CICC & + \\
\hline & 21569 & 21570 & CICC & + \\
\hline & 21565 & 22918 & CICC & + \\
\hline & 21919 & 22924 & CICC & + \\
\hline & 21599 & 21674 & CICC & + \\
\hline & 21551 & 21654 & CICC & + \\
\hline Vibrio parahaemolyticus & PVPA 0146 & & JX-CDC & - \\
\hline \multirow{2}{*}{ Staphylococcus aureus $(\mathrm{n}=3)$} & 26001 & 26002 & CMCC & - \\
\hline & 26003 & & CMCC & - \\
\hline \multirow[t]{2}{*}{ Bacillus cereus $(\mathrm{n}=4)$} & JDZ0121LY & D20063L & JX-CDC & - \\
\hline & JDZ0102Y & JA0098 & JX-CDC & - \\
\hline \multirow[t]{2}{*}{ Listeria monocytogenes $(\mathrm{n}=2)$} & 13932 & & ATCC & - \\
\hline & 54007 & & $\mathrm{CMCC}$ & - \\
\hline Listeria ivanovii & 19119 & & ATCC & - \\
\hline Listeria welshimeri & 35897 & & ATCC & - \\
\hline Listeria innocua & 11288 & & ATCC & - \\
\hline Listeria seeligeri & 35967 & & ATCC & - \\
\hline Escherichia coli & 44104 & & $\mathrm{CMCC}$ & \\
\hline Bacillus subtilis & 63501 & & CMCC & - \\
\hline Shigella sonnei & 29930 & & ATCC & \\
\hline Salmonella Enteritidis & 13076 & & ATCC & - \\
\hline Salmonella Typhimurium & 13311 & & ATCC & - \\
\hline Salmonella choleraesuis & 10708 & & ATCC & - \\
\hline Salmonella anatum & 9270 & & ATCC & - \\
\hline Salmonella Paratyphi A & 9150 & & ATCC & - \\
\hline Pseudomonas aeruginosa & 10104 & & $\mathrm{CMCC}$ & - \\
\hline
\end{tabular}

tion. The cell suspensions were pre-treated with SD before the PMA treatment. The PMA (Biotium Inc., Hayward, CA) was dissolved in 20\% dimethyl sulfoxide (Sun Nuclear, São Paulo, Brazil) to reach a final concentration of $1 \mathrm{mg} / \mathrm{mL}$ and was stored at $-20^{\circ} \mathrm{C}$ in the dark before used. The PMA was added to $500 \mu \mathrm{L}$ of dead or viable cells to obtain final concentrations of $0.2,0.4,0.6,0.8,1,5$, and $10 \mu \mathrm{g} / \mathrm{mL}$. The samples were incubated for $5 \mathrm{~min}$ in the dark and exposed to a 500-W halogen light at a $20-\mathrm{cm}$ distance for $5 \mathrm{~min}$. During exposure, the samples were occasionally shaken to ensure a complete reaction, and all samples were placed on ice to avoid excessive heating. Afterward, all samples were centrifuged at $12,000 \times g$ for 5 min at room temperature, and the recovered pellet was washed with PBS twice to get rid of the free PMA. The pellets were resuspended in $100 \mu \mathrm{L}$ of sterile water, and then the DNA was extracted for qPCR. All samples were carried out in triplicate.

\section{DNA Extraction and qPCR Condition}

All DNA were extracted using the water-boiling method. The treated samples were boiled for $15 \mathrm{~min}$ to release the genomic DNA, followed by centrifugation at $12,000 \times g$ for $5 \mathrm{~min}$ at room temperature to obtain the supernatant solution containing the genomic DNA. The collected DNA were stored at $-20^{\circ} \mathrm{C}$ until further use (Wang et al., 2015).

Primers were designed to amplify $121 \mathrm{bp}$ from the ITS of C. sakazakii using Oligo 6.0 software (http://www. oligo.net/). The forward primer was (5'-CGCTGCTGCATTTCTCCGTAAT-3') and the reverse primer was (5'-CCAGGGCATCCACCGTGTA-3'). The total reaction volume was $10 \mu \mathrm{L}$ including $5 \mu \mathrm{L}$ of SYBR Premix Ex Taq (TaKaRa, Biotech Co. Ltd., Dalian, China), $0.2 \mu \mathrm{L}$ of ROX reference dye, $0.2 \mu \mathrm{L}$ each of $10 \mathrm{mM}$ forward and reverse primers, $3.4 \mu \mathrm{L}$ of sterile water, and $1 \mu \mathrm{L}$ of the purified bacteria genomic DNA as a template. A $7900 \mathrm{HT}$ fast real-time PCR system (Applied Biosystems, Foster City, CA) was used for thermal cycling as follows: initial denaturation of DNA at $95^{\circ} \mathrm{C}$ for $30 \mathrm{~S}$, followed by 40 cycles of denaturation at $95^{\circ} \mathrm{C}$ for $5 \mathrm{~s}$, and annealing at $56^{\circ} \mathrm{C}$ for $1 \mathrm{~min}$. The qPCR assay was performed in triplicate-parallel analysis in 96-well plates. Sterile water was used in place of the DNA templates in negative controls to ensure the absence of contamination in the wells. All results were 
A)

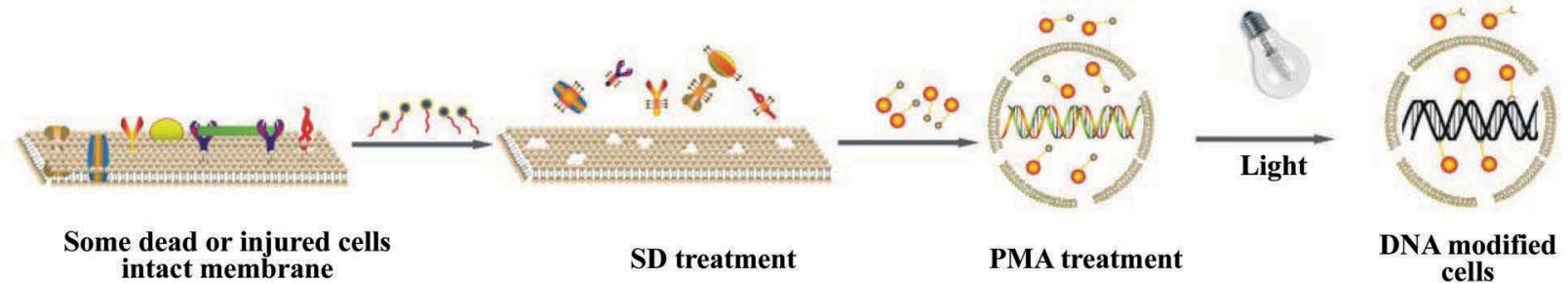
intact membrane
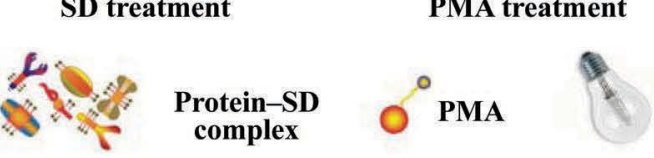

Halogen lamp

B)

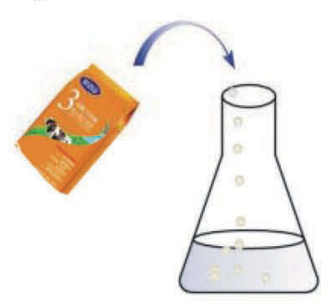

PIF sample

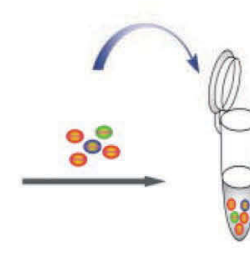

Inoculation

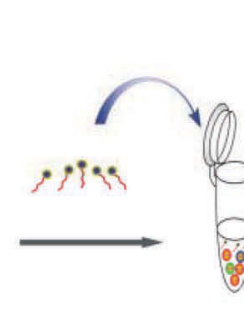

SD treatment

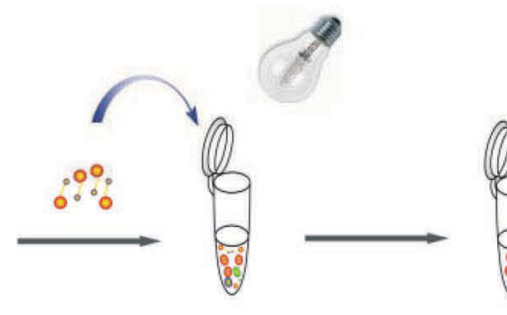

Wash and PMA treatment resuspension

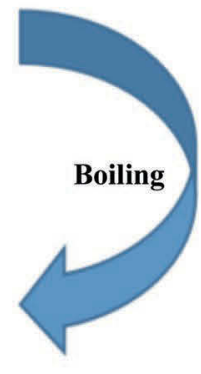

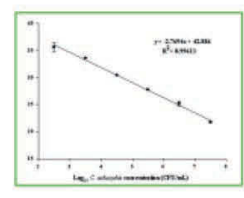

Standard curve design

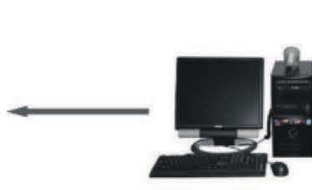

qPCR amplification

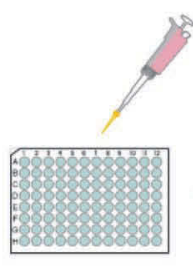

Sample adding

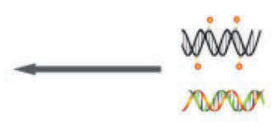

DNA extraction

Viable Cell ODead Cell Injured Cell $\odot$ DNA Modified Cell nowor Target DNA MONOL

PMA Wedded DNA

Figure 1. Schematic diagram of the combined use of sodium deoxycholate (SD) and propidium monoazide (PMA; A), and the assay process for the detection of viable Cronobacter sakazakii from powdered infant formula (PIF) by SD-PMA-quantitative PCR assay (B). Color version available online.

analyzed with SDS 2.3 software (Applied Biosystems, Foster City, CA).

\section{Standard Curve}

To establish a standard curve and the limit of detection (LOD), a serial 10-fold dilution of C. sakazakii $\left(10^{7} \mathrm{cfu} / \mathrm{mL}\right.$ to $\left.10^{2} \mathrm{cfu} / \mathrm{mL}\right)$ from pure culture that was pre-treated with SD and PMA was prepared, and DNA was extracted as described in the section DNA Extraction and qPCR Conditions. The standard curve was generated by plotting the DNA levels versus the corresponding experimental cycle threshold $(\mathbf{C t})$ value.

To compare the difference for enumerating in pure culture and spiked samples, another standard curve was drawn to analyze C. sakazakii contamination in PIF
(Wondersun Inc., Heilongjiang, China). Fifty microliters of 10-fold serial dilutions of overnight cultures was added to $450 \mu \mathrm{L}$ of PIF solution (1 g of PIF solid powder with $9 \mathrm{~mL}$ of PBS) to obtain the final C. sakazakii concentrations from $10^{7}$ to $10^{2} \mathrm{cfu} / \mathrm{mL}$. Subsequently, the cells were separated by centrifugation at $8,000 \times$ $g$ for $5 \mathrm{~min}$ at room temperature, washed, and resuspended in $500 \mu \mathrm{L}$ of PBS. This process was repeated until all remaining PIF matrix was removed. After treatment with SD and PMA, the separated cell pellets were resuspended in $100 \mu \mathrm{L}$ of sterile water. The DNA from $100-\mu \mathrm{L}$ aliquots of the treated cells was extracted as described above. The standard curve was established by plotting the concentration of DNA versus the experimental Ct value. All standard curves were based on 3 or more independent experiments. Figure 1B shows a schematic diagram of the entire process. 


\section{Enumeration of Viable C. sakazakii by Various qPCR Assays and Plate Count Assays}

To compare the accuracy of different methods of enumerating viable $C$. sakazakii using qPCR, PMA-qPCR, and SD-PMA-qPCR, 4 groups $(5-500 \mu \mathrm{L}$ portions in each group) of fresh C. sakazakii at an initial concentration of $10^{7} \mathrm{cfu} / \mathrm{mL}$ were prepared as described in the previous section. To obtain different concentrations of viable cells, all samples were immersed in water bath at $55^{\circ} \mathrm{C}$ for different periods of time $(0,2.5,5,7.5$, and 15 min), respectively, then cooled in $4^{\circ} \mathrm{C}$ for 5 min before treatment with SD or PMA. One of the 4 groups of cell suspensions was used for 10-fold dilutions that were spread on LB plates and incubated for $24 \mathrm{~h}$ before enumerations. The remaining 3 groups of cell suspension were treated as follows: the first group was treated with $4 \mu \mathrm{L}$ of SD (10\% wt/vol) and $2.5 \mu \mathrm{L}$ of PMA (1 mg/ $\mathrm{mL}$ ), the second group was only treated with $2.5 \mu \mathrm{L}$ of PMA $(1 \mathrm{mg} / \mathrm{mL})$, and the last group was not treated with SD or PMA. After treatment, all samples were centrifuged and the resulting pellet was resuspended in $100 \mu \mathrm{L}$ of sterile water. The DNA from $100-\mu \mathrm{L}$ cell suspensions was extracted using the water-boiling method for use in $\mathrm{qPCR}$.

\section{Quantitation of Viable Cells and Specificity Testing in Spiked Sample}

To validate the effect of SD-PMA-qPCR assay in a sample matrix, PIF were purchased from a local supermarket. All food samples were inspected for the absence of C. sakazakii or other bacteria. A series of concentrations $\left(10^{2}-10^{7} \mathrm{cfu} / \mathrm{mL}\right)$ of index viable bacteria was prepared as described in Materials and Methods. One gram of PIF mixed with $9 \mathrm{~mL}$ of $0.1 \%$ (wt/vol) peptone water was prepared and used as a liquid sample matrix. Each $50-\mu \mathrm{L}$ bacteria suspension from each group was added to $450 \mu \mathrm{L}$ of liquid sample matrix and mixed thoroughly with a vortex shaker. The cells were alternately washed and centrifuged at $8,000 \times g$ for 5 min at room temperature until the PIF matrix was removed. The washed cell pellets were resuspended in $100 \mu \mathrm{L}$ of sterile water before treatment with SD and PMA as described in the previous section before the DNA was isolated for a qPCR analysis.

To demonstrate the specificity of the developed detection method, the primers were tested for selectivity. As shown in Table 1, 14 species of C. sakazakii and 22 species of common foodborne pathogens were used for PCR (Xu et al., 2014). Staphylococcus aureus at $10^{7}$ $\mathrm{cfu} / \mathrm{mL}$ was added to serial dilutions of C. sakazakii $\left(10^{2}-10^{7} \mathrm{cfu} / \mathrm{mL}\right)$ that were added to $450 \mu \mathrm{L}$ of liquid sample matrix and subjected to SD and PMA treatment, and the DNA was extracted for qPCR analysis in triplicate samples.

\section{Statistical Analysis}

In this study, all data were log-transformed to obtain normally distributed residuals. Data were analyzed independently by one-way ANOVA with post hoc paired Student's t-test with Bonferroni correction for multiple testing using SPSS version 19 (SPSS Inc., Chicago, IL). Results with $P<0.05$ were considered statistically significant.

\section{RESULTS}

\section{Determination of the Optimal Concentration of SD in Dead and Injured Cells}

To evaluate the effect of SD on dead and injured cells, viable C. sakazakii $\left(10^{7} \mathrm{cfu} / \mathrm{mL}\right)$ were heat treated at different temperature $\left(50,55,60,65\right.$, and $\left.70^{\circ} \mathrm{C}\right)$ and incubated for various periods of time $(1,2.5$, and 5 min). The numbers of surviving viable cells were enumerated on $0.3 \%$ LB.

As shown on Table 2, the number of surviving viable cells indicated a reduction by 3 or $4 \log$ units after heat treatment at 55 to $70^{\circ} \mathrm{C}$ for 5 min compared with the initial bacteria concentration. The reduction in surviving viable cells was 1 or $2 \log$ units after heat treatment at $55^{\circ} \mathrm{C}$ for $2.5 \mathrm{~min}$ or $60^{\circ} \mathrm{C}$ for $1 \mathrm{~min}$. The number of surviving viable cells change within 1 log unit after heat treatment at $50^{\circ} \mathrm{C}$ for $2.5 \mathrm{~min}$. Thus, it was concluded that heat treatment at $55^{\circ} \mathrm{C}$ for $2.5 \mathrm{~min}$ or $60^{\circ} \mathrm{C}$ for 1 min was the most suitable condition to obtain viable cells with injured cells. The $60^{\circ} \mathrm{C}$ for 1 min condition was not used because it was too short of a treatment period to ensure accuracy of results.

To eliminate the influence of injured cells, the maximum SD concentration that had no effect on viable cells was determined. As shown in Figure 2, the number of viable cells recovered after SD treatment was highest at 0 to $0.04 \%$ (wt/vol). At higher SD concentrations between 0.08 to $0.1 \%$, no significant difference was found in the number of recovered viable cells $(P>$ $0.05)$. However, a significant difference was found in the number of viable cells after treatment with $0.5 \% \mathrm{SD}(P$ $<0.05$ ). Thus, a $0.08 \%$ SD was chosen to be the maximum SD concentration, which completely inhibited the injured cells but had no effect on viable C. sakazakii. The optimal incubation time with SD was taken at 20 min as previously published (Wang et al., 2015). 


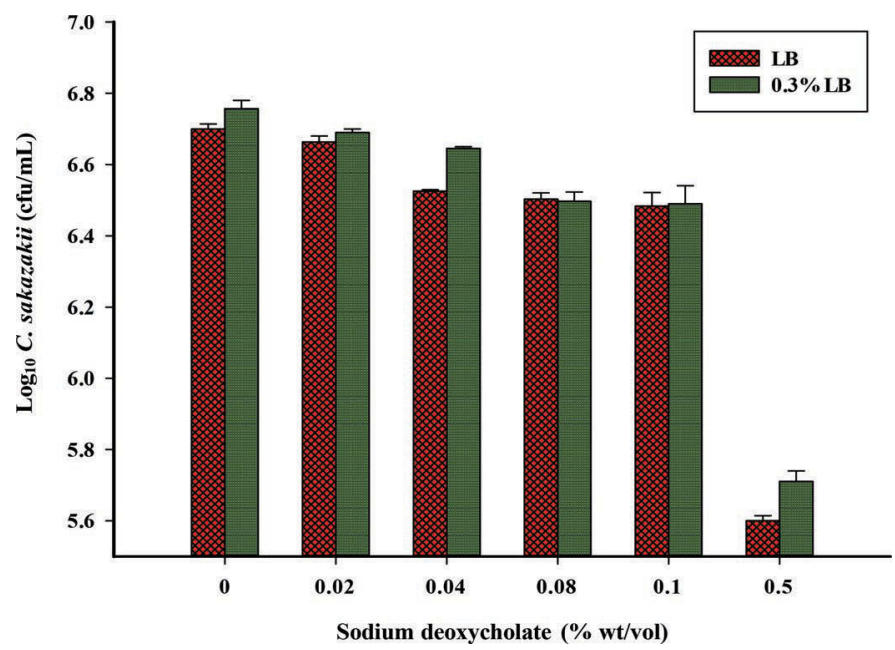

Figure 2. Optimization of the concentration of sodium deoxycholate (SD). The number of viable cells were enumerated by using plate counts on Luria-Bertani (LB) and $0.3 \%$ LB. Each bar represents the average number of viable cells enumerated on $\mathrm{LB}$ or $0.3 \% \mathrm{LB}$ of a triplicate study. Color version available online.

\section{Selection of the Optimal PMA Concentration}

The PMA-qPCR assay had been previously shown to selectively detect viable $E$. coli cells (Truchado et al., 2016). In this study, the most effective concentration of PMA to eliminate the interference of dead cells was established. As seen in Figure 3, after the viable cells were treated with $0.08 \% \mathrm{SD}$, an increase in PMA treatment concentration from 0 to $5 \mu \mathrm{g} / \mathrm{mL}$ showed a $\mathrm{Ct}$ value that remained constant at a mean value of 22.6. Treatment with $10 \mu \mathrm{g} / \mathrm{mL}$ of PMA obviously increased the $\mathrm{Ct}$ value to 27.9. However, for dead cells treated with $0.08 \% \mathrm{SD}$, the $\mathrm{Ct}$ value continuously increased with an increase in the PMA treatment concentration from 0 to $1 \mu \mathrm{g} / \mathrm{mL}$. The $\mathrm{Ct}$ value remained almost constant when the PMA concentration was between 1 and $5 \mu \mathrm{g} / \mathrm{mL}$. On the other hand, no Ct value was recorded when dead cells were treated with $10 \mu \mathrm{g} / \mathrm{mL}$ of PMA, which proved that the dead cells were inhibited for PCR amplification. These results indicated that

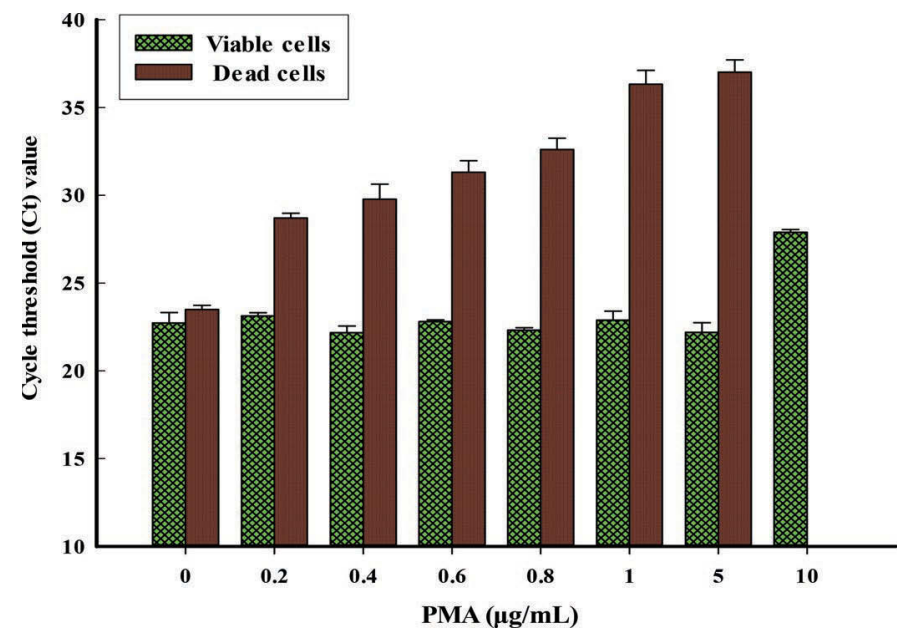

Figure 3. Optimization of the concentration of propidium monoazide (PMA). The effect of PMA was revealed by different cycle threshold (Ct) values from 7900HT fast real-time PCR system (Applied Biosystems, Foster City, CA). Each bar represents the average Ct value of the quantitative $\mathrm{PCR}$ reaction targeting the internal transcribed spacer (ITS gene) of a triplicate study. Color version available online.

treatment with $5 \mu \mathrm{g} / \mathrm{mL}$ of PMA was the suitable concentration to inhibit dead cells without affecting viable cells during PCR amplification. The results indicated that PMA at $10 \mu \mathrm{g} / \mathrm{mL}$ inhibited dead cells during PCR amplification, but also significantly affected the viable cells. Therefore, the optimal PMA concentration was chosen at $5 \mu \mathrm{g} / \mathrm{mL}$ to inhibit dead cells without significantly affecting the viable cells.

\section{Establishment of Standard Curves}

The optimized conditions for the SD-PMA-qPCR assay were used to establish the standard curve for the number of C. sakazakii detected. From Figure 4A, the standard curve for the pure culture showed a linear correlation $\left(\mathrm{R}^{2}=0.996\right)$. The amplification efficiency reached a maximum of $129.6 \%$, which was calculated using the equation: $\mathrm{E}=10^{-1 / \text { slope }}-1$. The calculated LOD of the new SD-PMA-qPCR assay for C. sakazakii was $3.3 \times 10^{2} \mathrm{cfu} / \mathrm{mL}$. To exhibit the usefulness of the

Table 2. Preparation of injured bacteria

\begin{tabular}{|c|c|c|c|}
\hline $\begin{array}{l}\text { Heat treatment } \\
\text { temperature } \\
\left({ }^{\circ} \mathrm{C}\right)\end{array}$ & $\begin{array}{l}\text { Time } \\
(\min )\end{array}$ & $\begin{array}{l}\text { Initial concentration } \\
\text { before heat treatment } \\
(\mathrm{cfu} / \mathrm{mL})\end{array}$ & $\begin{array}{c}\text { Final concentration after } \\
\text { heat treatment } \\
(\mathrm{cfu} / \mathrm{mL})\end{array}$ \\
\hline 70 & 5 & $3.5 \times 10^{7}$ & $2.6 \times 10^{3}$ \\
\hline 65 & 5 & $3.5 \times 10^{7}$ & $1.6 \times 10^{4}$ \\
\hline 60 & 5 & $3.5 \times 10^{7}$ & $1.2 \times 10^{4}$ \\
\hline & 1 & $2.9 \times 10^{7}$ & $1.7 \times 10^{6}$ \\
\hline 55 & 5 & $2.9 \times 10^{7}$ & $7.8 \times 10^{4}$ \\
\hline & 2.5 & $1.8 \times 10^{7}$ & $2.9 \times 10^{5}$ \\
\hline 50 & 2.5 & $3.5 \times 10^{7}$ & $1.1 \times 10^{7}$ \\
\hline
\end{tabular}


assay in real-world samples, which may exhibit interferences from the components of the samples, a standard curve using spiked PIF as matrix was established. As shown in Figure 4B, the LOD of the assay in spiked PIF was $4.4 \times 10^{2} \mathrm{cfu} / \mathrm{g}$. The amplification efficiency was $99.3 \%$ for the spiked matrix, and the linear dependent coefficient was 0.994 . The results indicated that the SD-PMA-qPCR assay could be applied to detect $C$. sakazakii in real samples.
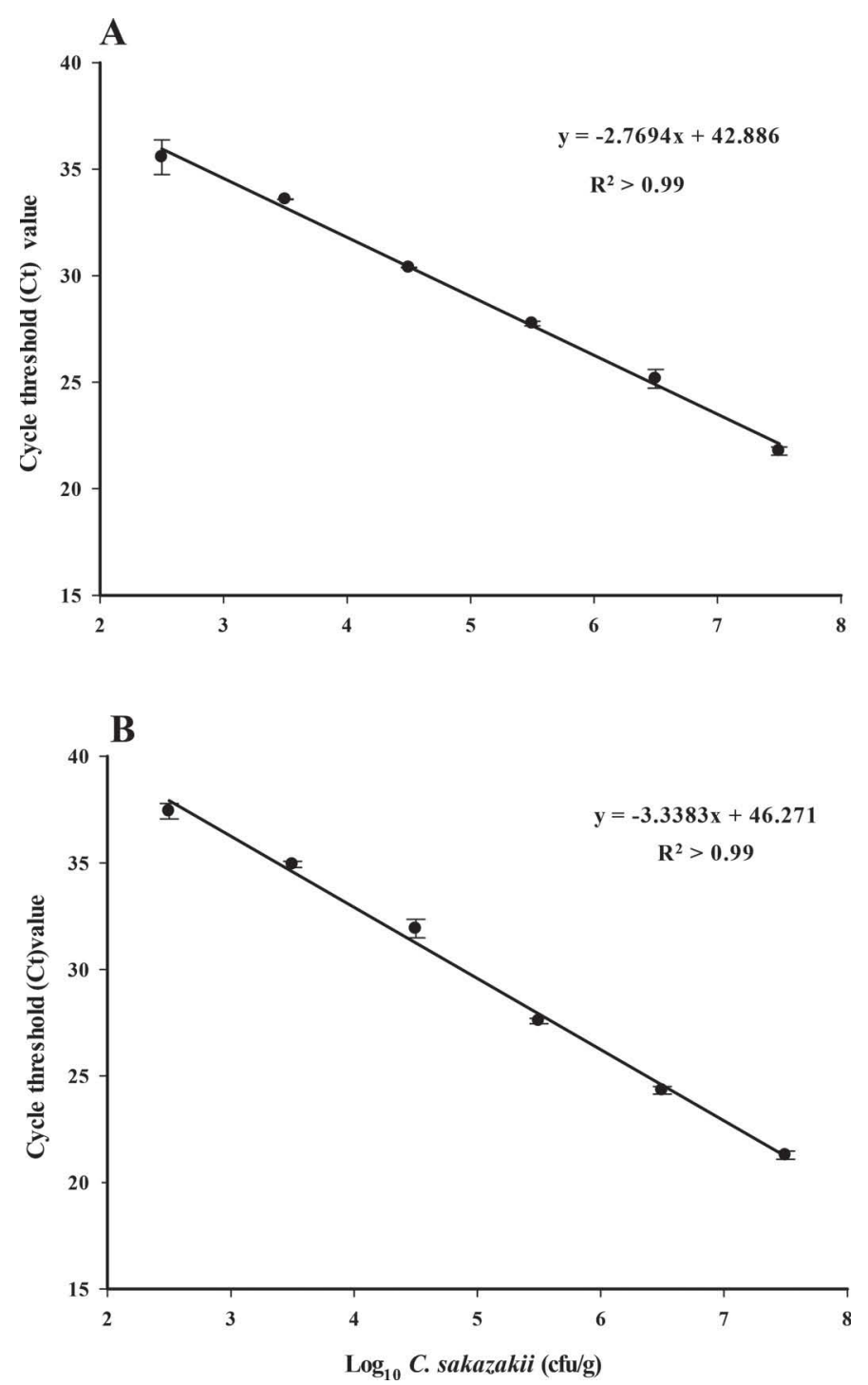

Figure 4. Establishment of standard curve. Plots of cycle threshold (Ct) values acquired for samples treated with sodium deoxycholate (SD) and propidium monoazide (PMA) against the log numbers of viable Cronobacter sakazakii $\left(3.3 \times 10^{2}\right.$ to $\left.3.3 \times 10^{7} \mathrm{cfu} / \mathrm{mL}\right)$ in pure culture (A) and in spiked powdered infant formula (PIF) matrix (B). Mean cycle threshold (Ct) values of triplicate assays were plotted against the number of viable cells per milliliter for each pure culture or per gram for each PIF matrix.

\section{Comparison of the Enumeration of Viable C. sakazakii by $q P C R, P M A-q P C R, S D-P M A-q P C R$, and Plate Count Assay}

To compare the accuracy of qPCR, PMA-qPCR, or SD-PMA-qPCR assay, viable C. sakazakii were enumerated in the presence of different concentrations of dead cells or injured cells. Target bacteria $\left(10^{7} \mathrm{cfu} / \mathrm{mL}\right)$ were treated in a $55^{\circ} \mathrm{C}$ water bath for various lengths of time: $0,2.5,5,7.5$, and 15 min, respectively. Surviving cells were enumerated with qPCR, PMA-qPCR, and SD-PMA-qPCR assay. As shown in Figure 5, no significant difference was found in the number of viable cells enumerated using qPCR assay after the cell suspension was heat treated at various lengths of time $(P>$ 0.05). When qPCR assay was combined with PMA, the results showed a higher viable cell number compared with the plate count assay. As expected, no significant difference was present in the number of viable cells between SD-PMA-qPCR assay and plate count assay $(P>0.05)$. This could be attributed to the fact that the SD combined with PMA eliminated the dead cells and injured cells from affecting the number of viable cells enumerated using qPCR. These results confirmed that the qPCR assay combined with SD and PMA was a suitable assay to detect viable $C$. sakazakii without interference of dead or injured cells.

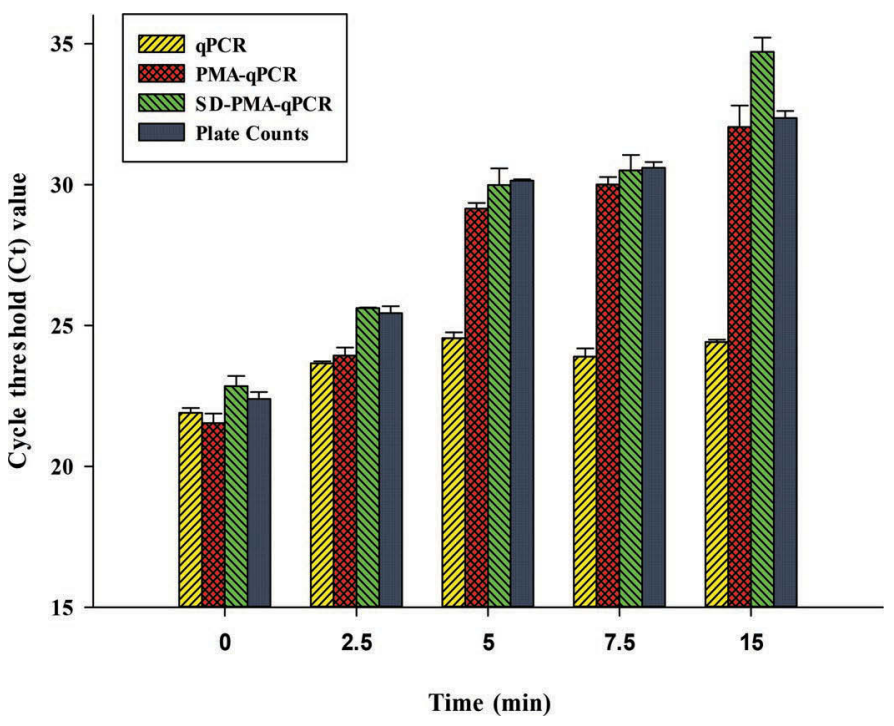

Figure 5. Enumeration of viable Cronobacter sakazakii by using the optimized quantitative PCR (qPCR), propidium monoazide (PMA)quantitative PCR, sodium deoxycholate (SD)-PMA-qPCR, and plate counts method in pure culture. The cycle threshold $(\mathrm{Ct})$ values from the plate count methods were obtained from the standard curve from pure culture. Each bar represents the average $\mathrm{Ct}$ value of the quantitative PCR reaction targeting the internal transcribed spacer (ITS gene) of a triplicate study. Color version available online. 


\section{Evaluation of the Specificity of SD-PMA-qPCR Assay}

To evaluate the specificity of the primers, target DNA and nontarget DNA from the strains shown in Table 1 were used. The results revealed that only C. sakazakii species gave a positive signal (data not shown). Subsequently, the specificity and quantitative effect of SD-PMA-qPCR assay was assessed to detect the target bacteria $\left(10^{2}-10^{7} \mathrm{cfu} / \mathrm{mL}\right)$ in the presence of $S$. aureus $\left(10^{7} \mathrm{cfu} / \mathrm{mL}\right)$ in spiked PIF. The results shown in Figure 6 exhibited a standard curve with good linear correlation $\left(\mathrm{R}^{2}=0.990\right)$ with an amplification efficiency up to $106 \%$. Compared with the standard curves for the samples in growth media, the spiked matrix showed no significant difference with a LOD at $5.6 \times 10^{2} \mathrm{cfu} / \mathrm{g}(P>0.05)$. These results indicated that the SD-PMA-qPCR was a specific assay to detect target strains in the presence of other nontarget strains.

\section{DISCUSSION}

As a main food source for newborns, PIF plays an important role in infant health. Since 2004, the FAO/ World Health Organization has put forward a list of bacterial pathogens including $C$. sakazakii that pose a serious threat for infant health (World Health Organization, 2004; FAO, 2008). Thus, the safety of PIF must be seriously evaluated in terms of $C$. sakazakii concentration. Thus, a rapid and specific detection method is needed to detect $C$. sakazakii in infant food.

In the qPCR method, choice of primer is the key to ensure high sensitivity and high specificity of the assay. Among the possible bacterial components that can be used as primers are the rRNA operons. The bacterial rRNA operons are generally composed of the 5S rRNA gene, $16 S$ rRNA gene, $t R N A$, spacer, and $23 S$ $r R N A$ gene. Most variations in sequences and lengths were discovered in the ITS regions of different bacteria species (Liu et al., 2006a). In this study, we chose ITS sequences to design primers and generated a 121-bp fragment DNA product. This resulted in high specificity for the designed primers that only targeted the 14 bacteria strains of C. sakazakii, which showed the expected bands on all the chosen strains. This proved that the primers had a high exclusivity and could be applied to specifically detect $C$. sakazakii without interference from nontarget bacteria.

Recently, a qPCR assay combined with PMA has been a popular tool for distinguishing viable bacteria (Xiao et al., 2015; Soejima et al., 2016; Truchado et al., 2016). However, general PMA-qPCR did not completely eliminate the interference of dead bacteria wherein some dead bacteria served for DNA amplification. This could affect the accuracy of the detection of

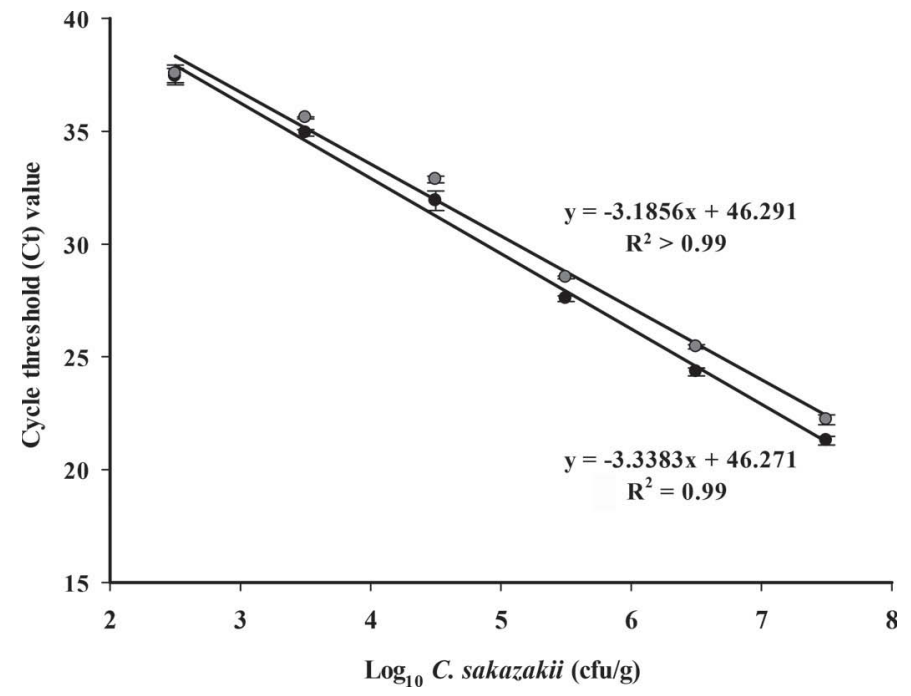

Figure 6. Sodium deoxycholate (SD)-propidium monoazide (PMA)-quantitative PCR detection of Cronobacter sakazakii in spiked powdered infant formula (PIF) matrix. A standard curve was established using total DNA from 10-fold serial dilutions of new pure bacterial culture at $3.3 \times 10^{2}$ to $3.3 \times 10^{7} \mathrm{cfu} / \mathrm{mL}$ in PIF in the presence of Staphylococcus aureus $\left(10^{7} \mathrm{cfu} / \mathrm{mL}\right)$. Mean cycle threshold $(\mathrm{Ct})$ values of triplicate assays were plotted against the number of viable cells per gram for each PIF matrix.

viable C. sakazakii, causing a false assessment of PIF quality. In this study, some dead or injured cells still had a complete membrane that prevented PMA permeation. To solve this problem, SD was applied to the PMA-qPCR assay (Figure 2). The SD as an anionic surfactant was applied to enhance PMA permeation of damaged cell membrane, but it had no influence in viable cells (Nkuipou-Kenfack et al., 2013). Therefore, the concentration of SD and PMA were optimized in our work. As described in Figure 3, the results seemed to indicate that this method could not completely inhibit dead cells without affecting viable cells during PCR amplification. However, in our work, very high numbers of target dead bacteria $\left(10^{7} \mathrm{cfu} / \mathrm{mL}\right)$ were prepared for optimization of PMA concentration; thus, it may be that very few dead cells are not inhibited because of a high concentration of dead cells, as reported by Cattani et al. (2016). There are very few situations in which an actual PIF sample could be contaminated by such high numbers of pathogens (either viable or dead); in spike sample experiments, we found that low numbers of target dead bacteria could be completely inhibited (no amplification signal) by optimal PMA concentration. Therefore, the established method is capable of inhibiting dead cells to solve the problem of false positives with real sample detection.

Due to the interference from the complex composition of PIF that was spiked with the target bacteria, it was very difficult to extract the bacterial DNA. To 
circumvent this, most studies use a DNA extraction kit, but this is costly, time consuming, and the LOD can only reach $10^{2} \mathrm{cfu} / \mathrm{mL}$ (Dong et al., 2013). In this study, the DNA was extracted using the water-boiling method and the LOD was $3.3 \times 10^{2} \mathrm{cfu} / \mathrm{mL}$ in pure culture (Figure $4 \mathrm{~A}$ ), and $4.4 \times 10^{2} \mathrm{cfu} / \mathrm{g}$ in PIF matrix (Figure 4B). This demonstrated that the SD-PMA-qPCR assay exhibited a high sensitivity for viable $C$. sakazakii. The assay exhibited a similar LOD between the sample in a matrix and the sample in culture medium. Comparison between qPCR, PMA-qPCR, and SD-PMA-qPCR assay with the plate count method indicated a good correlation between SD-PMA-qPCR assay and plate count method for the number of viable cells. Thus, it was demonstrated that the SD-PMA-qPCR assay was accurate and proves useful for the detection of viable $C$. sakazakii in the PIF matrix.

In our previous work, we built an immunomagnetic separation (IMS)-SD-PMA-qPCR assay for rapidly and accurately detecting viable $E$. coli without the interference of injured or dead cells (Wang et al., 2014b). The ingenious application of IMS for enrichment allowed the process to be faster and exhibited LOD of $10^{2}$ $\mathrm{cfu} / \mathrm{mL}$ in the milk matrix. However, this study was the first to report the use of a combined SD-PMA-qPCR assay for the specific detection of viable $C$. sakazakii in the presence of multiple strains of bacteria in a real PIF sample. In our previous work, some drawbacks included complex operations and expensive reagents (e.g., antibody) for application of IMS. However, in our present work, we also could obtain an expected result without application of IMS. Compared with a regular qPCR assay, our method is time saving and cost effective and its sensitivity could achieve to $10^{2} \mathrm{cfu} / \mathrm{mL}$ in real PIF. This assay would play a vital role in rapid and accurate detection of viable C. sakazakii in the future.

\section{CONCLUSIONS}

This study demonstrated that the combination of SD and PMA with qPCR assay was more accurate than PMA-qPCR and qPCR alone for the detection of viable C. sakazakii in pure samples and in PIF matrix. Treatment with a combination of SD and PMA before qPCR allowed for the accurate quantification of viable cells without interference from injured and dead cells. The optimized assay parameters allowed the specific detection of $3.3 \times 10^{2} \mathrm{cfu} / \mathrm{mL}$ viable cells in pure culture and $4.4 \times 10^{2} \mathrm{cfu} / \mathrm{g}$ in spiked PIF. It also allowed the detection $5.6 \times 10^{2} \mathrm{cfu} / \mathrm{g}$ of viable cells in the presence of $S$. aureus $\left(10^{7} \mathrm{cfu} / \mathrm{mL}\right)$. The SD-PMA-qPCR assay developed in this study holds promise for rapid, accurate, specific, and sensitive detection of viable $C$. sakazakii in real PIF to monitor the quality of PIF.

\section{ACKNOWLEDGMENTS}

The work was supported by the Research Foundation for Young Scientists of State Key Laboratory of Food Science and Technology, Nanchang University, China (No. SKLF-QN-201504), and Science and Technology Planning Project of Jiangxi Province (20142BBG70031).

\section{REFERENCES}

Arroyo, C., S. Condon, and R. Pagan. 2009. Thermobacteriological characterization of Enterobacter sakazakii. Int. J. Food Microbiol. 136:110-118.

Cai, X.-Q., H.-Q. Yu, Z.-X. Ruan, L.-L. Yang, J.-S. Bai, D.-Y. Qiu, Z.-H. Jian, Y.-Q. Xiao, J.-Y. Yang, L. Thanh Hoa, and X.-Q. Zhu. 2013. Rapid detection and simultaneous genotyping of Cronobacter spp. (formerly Enterobacter sakazakii) in powdered infant formula using real-time PCR and high resolution melting (HRM) analysis. PLoS One 8:e67082.

Cattani, F., V. C. Barth Jr., J. S. R. Nasário, C. A. S. Ferreira, and S. D. Oliveira. 2016. Detection and quantification of viable Bacillus cereus group species in milk by propidium monoazide quantitative real-time PCR. J. Dairy Sci. 99:2617-2624.

Chen, W., L. Ai, J. Yang, J. Ren, Y. Li, and B. Guo. 2013. Development of a PCR assay for rapid detection of Cronobacter spp. from food. Can. J. Microbiol. 59:656-661.

Dong, X., Q. Wu, K. Wu, and J. Zhang. 2013. Real-time PCR targeting $O m p A$ gene for detection of Cronobacter spp. in powdered infant formula. Food Sci. Biotechnol. 22:309-313.

FAO. 2008. Enterobacter sakazakii (Cronobacter spp.) in powdered follow-up formulae. Microbiological Risk Assessment Series no. 15. Food and Agriculture Organization, Rome, Italy.

Farmer, J., III, M. Asbury, F. Hickman, D. J. Brenner, and E. S. Group. 1980. Enterobacter sakazakii: A new species of "Enterobacteriaceae" isolated from clinical specimens. Int. J. Syst. Evol. Microbiol. 30:569-584.

Fittipaldi, M., A. Nocker, and F. Codony. 2012. Progress in understanding preferential detection of live cells using viability dyes in combination with DNA amplification. J. Microbiol. Methods 91:276-289.

Hu, S., Y. Yu, R. Li, X. Wu, X. Xiao, and H. Wu. 2016. Rapid detection of Cronobacter sakazakii by real-time PCR based on the cgcA gene and TaqMan probe with internal amplification control. Can. J. Microbiol. 191:191-200.

Hunter, C. J., and J. F. Bean. 2013. Cronobacter: An emerging opportunistic pathogen associated with neonatal meningitis, sepsis and necrotizing enterocolitis. J. Perinatol. 33:581-585.

Iversen, C., N. Mullane, B. McCardell, B. D. Tall, A. Lehner, S. Fanning, R. Stephan, and H. Joosten. 2008. Cronobacter gen. nov., a new genus to accommodate the biogroups of Enterobacter sakazakii, and proposal of Cronobacter sakazakii gen. nov., comb. nov., Cronobacter malonaticus sp. nov., Cronobacter turicensis sp. nov., Cronobacter muytjensii sp. nov., Cronobacter dublinensis sp. nov., Cronobacter genomospecies 1, and of three subspecies, Cronobacter dublinensis ssp. dublinensis ssp. nov., Cronobacter dublinensis ssp. lausannensis ssp. nov. and Cronobacter dublinensis ssp. lactaridi ssp. nov. Int. J. Syst. Evol. Microbiol. 58:1442-1447.

Kang, S. E., Y. Nam, and K. Hong. 2007. Rapid detection of Enterobacter sakazakii using TaqMan real-time PCR assay. J. Microbiol. Biotechnol. 17:516-519.

Linder, K., and J. D. Oliver. 1989. Membrane fatty acid and virulence changes in the viable but nonculturable state of Vibrio vulnificus. Appl. Environ. Microbiol. 55:2837-2842.

Liu, Y., X. N. Cai, X. Zhang, Q. L. Gao, X. C. Yang, Z. J. Zheng, M. H. Luo, and X. T. Huang. 2006a. Real time PCR using TaqMan and SYBR Green for detection of Enterobacter sakazakii in infant formula. J. Microbiol. Methods 65:21-31. 
Liu, Y., Q. L. Gao, X. Zhang, Y. M. Hou, J. L. Yang, and X. T. Huang. 2006b. PCR and oligonucleotide array for detection of Enterobacter sakazakii in infant formula. Mol. Cell. Probes 20:11-17.

Morgan, J. A., G. Rhodes, and R. W. Pickup. 1993. Survival of nonculturable Aeromonas salmonicida in lake water. Appl. Environ. Microbiol. 59:874-880.

Nkuipou-Kenfack, E., H. Engel, S. Fakih, and A. Nocker. 2013. Improving efficiency of viability-PCR for selective detection of live cells. J. Microbiol. Methods 93:20-24.

Norberg, S., C. Stanton, R. P. Ross, C. Hill, G. F. Fitzgerald, and P. D. Cotter. 2012. Cronobacter spp. in powdered infant formula. J. Food Prot. 75:607-620.

Park, S., S. Shukla, Y. Kim, S. Oh, S. Hun Kim, and M. Kim. 2012. Development of sandwich enzyme-linked immunosorbent assay for the detection of Cronobacter muytjensii (formerly called Enterobacter sakazakii). Microbiol. Immunol. 56:472-479.

Soejima, T., J.-i. Minami, J.-z. Xiao, and F. Abe. 2016. Innovative use of platinum compounds to selectively detect live microorganisms by polymerase chain reaction. Biotechnol. Bioeng. 113:301-310.

Truchado, P., M. I. Gil, T. Kostic, and A. Allende. 2016. Optimization and validation of a PMA qPCR method for Escherichia coli quantification in primary production. Food Contr. 62:150-156.

van Acker, J., F. de Smet, G. Muyldermans, A. Bougatef, A. Naessens, and S. Lauwers. 2001. Outbreak of necrotizing enterocolitis associated with Enterobacter sakazakii in powdered milk formula. J. Clin. Microbiol. 39:293-297.

Wang, H., C. O. Gill, and X. Yang. 2014a. Use of sodium lauroyl sarcosinate (sarkosyl) in viable real-time PCR for enumeration of Escherichia coli. J. Microbiol. Methods 98:89-93.
Wang, L., P. Li, Z. Zhang, Q. Chen, Z. P. Aguilar, H. Xu, L. Yang, F. Xu, W. Lai, Y. Xiong, and H. Wei. 2014b. Rapid and accurate detection of viable Escherichia coli O157:H7 in milk using a combined IMS, sodium deoxycholate, PMA and real-time quantitative PCR process. Food Contr. 36:119-125

Wang, L., C. Ye, H. Xu, Z. P. Aguilar, Y. Xiong, W. Lai, and H. Wei. 2015. Development of an SD-PMA-mPCR assay with internal amplification control for rapid and sensitive detection of viable Salmonella spp., Shigella spp. and Staphylococcus aureus in food products. Food Contr. 57:314-320.

World Health Organization. 2004. Enterobacter sakazakii and other microorganisms in powdered infant formula: Meeting report. No. 6. Food \& Agriculture Organization, Rome, Italy..

Xiao, L., Z. Zhang, X. Sun, Y. Pan, and Y. Zhao. 2015. Development of a quantitative real-time PCR assay for viable Salmonella spp. without enrichment. Food Contr. 57:185-189.

Xu, F., P. Li, X. Ming, D. Yang, H. Xu, X. Wu, N. P. Shah, and H. Wei. 2014. Detection of Cronobacter species in powdered infant formula by probe-magnetic separation PCR. J. Dairy Sci. 97:60676075.

Yang, X., M. Badoni, and C. O. Gill. 2011. Use of propidium monoazide and quantitative PCR for differentiation of viable Escherichia coli from E. coli killed by mild or pasteurizing heat treatments. Food Microbiol. 28:1478-1482.

Zimmermann, J., H. Schmidt, M. J. Loessner, and A. Weiss. 2014 Development of a rapid detection system for opportunistic pathogenic Cronobacter spp. in powdered milk products. Food Microbiol. 42:19-25. 